\title{
Qualified Person Type Code
}

National Cancer Institute

\section{Source}

National Cancer Institute. Qualified Person Type Code. NCI Thesaurus. Code C94035.

A coded value specifying the kind of qualification a person has. 